\title{
The Polymorphism in Interleukin-6-597 G/A Gene and their Levels on Type 2 Diabetic Patients
}

\author{
Zaimah Z Tala ${ }^{1}$, Nurfida Khairina Arrasyid ${ }^{2}$, Sanny Sanny ${ }^{3}$, Mutiara Indah Sari ${ }^{4 *}$ \\ ${ }^{1}$ Department of Clinical Nutrition, Faculty of Medicine, Universitas Sumatera Utara, Medan, Indonesia; ${ }^{2}$ Department of \\ Parasitology, Faculty of Medicine, Universitas Sumatera Utara, Medan, Indonesia; ${ }^{3}$ Department of Medical Education, Faculty \\ of Medicine, Universitas Sumatera Utara, Medan, Indonesia; ${ }^{4}$ Departement of Biochemistry, Faculty of Medicine, Universitas \\ Sumatera Utara, Medan, Indonesia
}

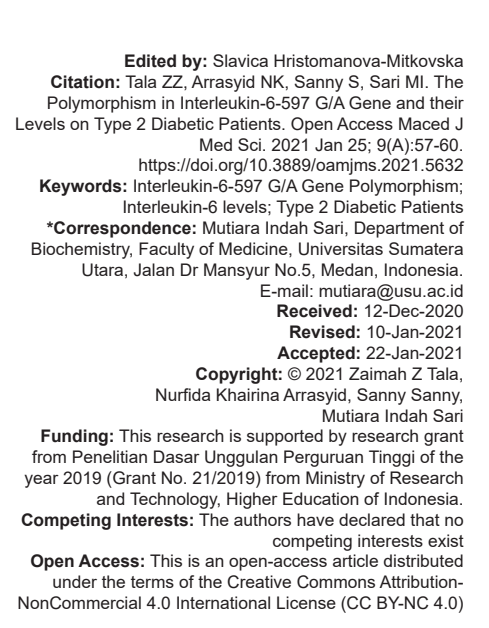

\begin{abstract}
BACKGROUND: Interleukin-6 (IL-6) pro-inflammatory cytokines play a role in the pathogenesis of inflammatory reactions in type 2 diabetes mellitus (T2DM). The $-597 \mathrm{G} / \mathrm{A}$ is one of IL-6 gene polymorphisms that are associated
\end{abstract} with the T2DM risk.

AIM: This study aimed to observe the polymorphism in IL-6-597 G/A gene and their levels on type 2 diabetic patients at Universitas Sumatera Utara Hospital.

MATERIALS AND METHODS: IL-6 -597 G/A gene polymorphisms and levels were done in 80 type 2 diabetic patients. The levels of IL- 6 were performed by enzyme-linked immunosorbent assay method. Analysis of IL-6$597 \mathrm{G} / \mathrm{A}$ gene polymorphism was done using polymerase chain reaction (PCR) and restriction fragment length polymorphism. The PCR products were cut by Fokl restriction enzyme and then visualized with $4 \%$ agarose.

RESULTS: This study showed that the genotype frequency of GG and GA was $97.5 \%$ and $2.5 \%$, respectively; however, no A/A genotype shown in this population. IL-6 levels were higher in GG genotype group compare to $G A+A A$ genotype group, with the association were significant $(p<0.05)$.

CONCLUSION: This study indicated that GG genotype was common genotype in the IL-6-597 G/A gene polymorphism and the polymorphism was significantly with the IL-6 levels.

\section{Introduction}

The International Diabetes Federation estimates that the number of people developing diabetes mellitus (DM) in the world will increase from 240 million in 2007 to 380 million in 2025 [1]. In Asia, Indonesia got the third ranks as the highest number of diabetic patients, after India and China [2]. DM is able to kill 3.4 million people in 2004 , and $80 \%$ of deaths due to DM occurred in developing countries [3], [4].

Nearly $90 \%$ of diabetic in the world were type 2 DM (T2DM). T2DM mostly occurs in the adult age, although it has now been found in adolescents [5]. Chronic hyperglycemia in T2DM occurs due to decreased tissue sensitivity to insulin activity or insulin resistance. Insulin resistance is a condition when insulin in blood is unable to phosphorylate the substrate receptors in the target cell so that there is a decrease uptake glucose into the cell [6].

Genetic factors play a role in insulin resistance [7]. It is estimated that $30-70 \%$ of the T2DM risk can be associated to genetics. Recently, the study has identified the candidate cytokine genes involved in the pathogenesis of T2DM, one of it is Interleukin-6 (IL-6). The production of these cytokines occurs through IL-6 gene expression located on chromosome 7p15-p21 [8].

Single nucleotide polymorphisms (SNPs) are changes in one of nucleotide or gene variations that are found by human deoxyribonucleic acid (DNA) sequencing technique [9]. SNPs in IL-6 gene can influence the level of IL-6 protein expression. Several IL-6 gene SNPs in the IL-6 promoter region have been identified such as SNP rs1800797 (-597 G/A or -598 $\mathrm{G} / \mathrm{A})$, rs1800796 (-572 G/C), and rs1800795 (-174 $\mathrm{G} / \mathrm{C}$ ) [10]. The $-597 \mathrm{G} / \mathrm{A}$ is one of IL-6 polymorphisms that are associated with the T2DM risk [11], [12]. Variants of the IL-6-597 G/A gene are GG, GA, AA genotypes, and $G$ and $A$ alleles [8].

Previous studies in several populations showed that the distribution of $A$ allele in IL-6-597 G/A was significantly related to IL- 6 activity or IL- 6 levels. IL-6 activity in humans is needed in the body's defense 
mechanism, immune response, and hematopoiesis. IL-6 is produced by various cells including monocytes, macrophages, fibroblasts, T-helper 2 cells, and endothelial cells [13].

This study aimed to observe the polymorphism in IL-6-597 G/A gene and their levels on type 2 diabetic patients at Universitas Sumatera Utara (USU) Hospital.

\section{Materials and Methods}

A total of 80 type 2 diabetic patients were recruited at Endocrinology Polyclinic USU Hospital. All the subjects enrolled must meet eligibility criteria based on the inclusion/exclusion criteria. The inclusion criteria were age 35-79 years, diagnosed with T2DM since 6 months ago, willing to participate as a study subject by signing an informed consent that has been approved by the Faculty of Medicine, USU-Haji Adam Malik General Hospital ethics committee No 447/2019. Subject of the study was excluded if the subject was suffering from malignant diseases, chronic infectious diseases, anemia, pregnancy, and consuming vitamins/ supplements.

Fasting glucose examination was done in the morning after the subject underwent fasting 10-12 h using Cobas 6000 analyzer. IL-6 levels were performed by enzyme-linked immunosorbent assay (ELISA) method with the principle of double antibody sandwich with biotin streptavidin, using a commercial ELISA kit (BioLegend). The sensitivity from this kit is $4 \mathrm{pg} / \mathrm{ml}$. The content was read by a microplate reader at a wavelength of $450 \mathrm{~nm}$. Polymorphism analysis was done by the initial stages of isolating the DNA of blood samples from study subjects. Two hundred microliters of blood from 80 patients were isolated using the Promega Extraction Kit. The DNA isolation procedure was carried out according to the protocol contained in the kit.

Isolated DNA was amplified using the polymerase chain reaction (PCR). $\mathrm{PCR}$ reaction was done in $25 \mu \mathrm{L}$ consist of each $1 \mu \mathrm{L}$ forward and reverse primer, 12.5 uL GoTaq ${ }^{\circledR}$ Green Master Mix (Promega, USA), 2uL DNA sample, and $8.5 \mathrm{dH} 2 \mathrm{O}$. The primers used refer to previous study [14]. PCR was carried out with an initial denaturation step at $95^{\circ} \mathrm{C}$ for $4 \mathrm{~min}$, continued with 30 cycles of denaturation at $95^{\circ} \mathrm{C}$ for $30 \mathrm{~s}$, annealing at $57^{\circ} \mathrm{C}$ for $30 \mathrm{~s}$, polymerization at $72^{\circ} \mathrm{C}$ for $30 \mathrm{~s}$, and after final cycle, there is a final polymerization at $72^{\circ} \mathrm{C}$ for $5 \mathrm{~min}$.

PCR products were analyzed by electrophoresed using agarose $2 \%$. The PCR products were then analyzed through restriction fragment length polymorphism (RFLP) method by cutting DNA gene sequence using Fokl rectiction enzyme. RFLP products were analyzed by electrophoresed using agarose $4 \%$ at 100 volt for $1 \mathrm{~h}$. Furthermore, electrophoresis results were detected using Gel Doc 1000 (Biorad, USA) to be visualized with ultraviolet light. Homozygote GG genotypes are shown in DNA fragments $525 \mathrm{bp}, \mathrm{GA}$ heterozygote is shown 3 bands at $525 \mathrm{bp}, 468 \mathrm{bp}$, and $57 \mathrm{bp}$, homozygote AA genotype is shown 2 bands at $468 \mathrm{bp}$ and $57 \mathrm{bp}$.

The results were analyzed using SPSS version 21. Genotype distribution of IL-6 gene polymorphisms was calculated by direct counting and displayed descriptively. The relationship of IL-6-597 G/A gene polymorphisms with IL-6 levels was analyzed using Mann-Whitney U-test.

\section{Results}

The study has been conducted on type 2 diabetic outpatient at Endocrinology Clinic USU Hospital. Fasting glucose levels and IL-6 levels of the study sample data are shown in Table 1.

Table 1: Characteristics of studied groups

\begin{tabular}{ll}
\hline Characteristics $\mathrm{n}=80$ & Median (Min-Max) \\
\hline Fasting glucose levels (mg/dl) & $196.00(63.00-542.00)$ \\
IL-6 (pg/ml) & $49.85(8.75-188.00)$ \\
\hline IL-6: Interleukin-6. &
\end{tabular}

PCR product of IL-6 gene and RFLP product from Fokl enzyme restriction (IL-6-597 G/A) visualization showed in Figures 1 and 2.

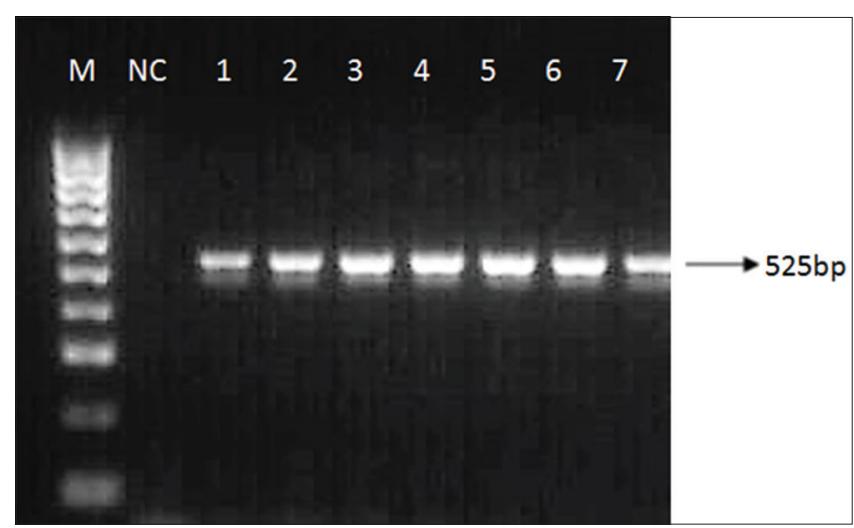

Figure 1: Polymerase chain reaction products analysis of Interleukin (IL)-6 gene visualized in $2 \%$ agarose gel electrophoresis. Lane $M$ is a 100 bp DNA ladder, lane 2 is a negative control, and lanes 1-7 represent IL-6 gene (525 bp)

Genotype and allele distribution of IL-6-597 G/A from this population are showed in Table 2.

Table 2: Genotypes and alleles distribution of IL-6-597 G/A

\begin{tabular}{lll}
\hline Genotype & $\mathrm{N}$ & $\%$ \\
\hline GG & 78 & 97.5 \\
GA & 2 & 2.5 \\
AA & 0 & 0 \\
\hline Alel & $\mathrm{N}$ & $\%$ \\
\hline G & 158 & 98.75 \\
A & 2 & 1.25 \\
\hline IL-6: Interleukin-6. & &
\end{tabular}




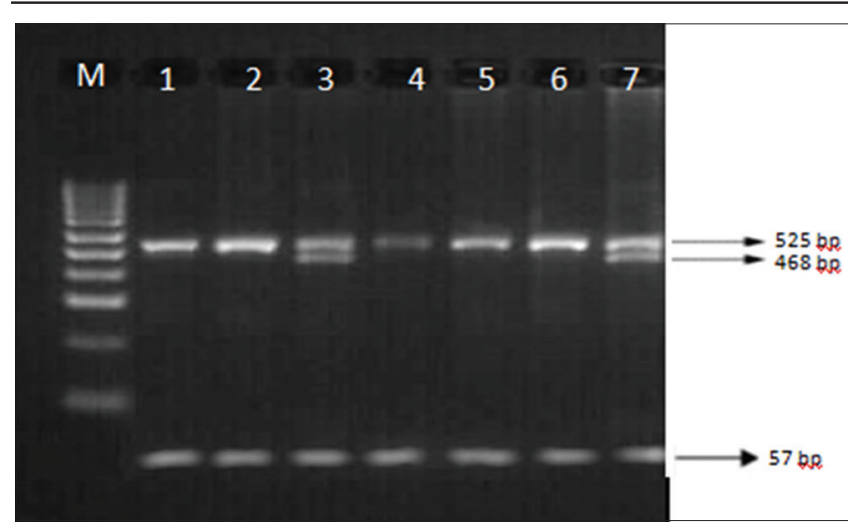

Figure 2: Polymerase chain reaction-restriction fragment length polymorphism of interleukin -6-597 G/A gene polymorphism visualized in $4 \%$ agarose gel electrophoresis. Lane $M$ is a 100 bp DNA ladder, lanes 1, 2, 4, 5, and 6 represent homozygote GG (525 bp), lanes 3 and 7 represent heterozygote GA (525 bp, 468 bp, and $57 \mathrm{bp}$ ), homozygote AA was not found in this population

Table 3: IL-6 levels found in IL-6-597 G/A genotypes

\begin{tabular}{lll}
\hline Genotype & $\mathrm{IL}-6(\mathrm{pg} / \mathrm{ml})$ & $\mathrm{p}$-value \\
\hline GG & $41.19 \pm 4.4$ & 0.014 \\
GA+AA & $13.50 \pm 0.1$ & \\
\hline IL-6: Interleukin-6. & &
\end{tabular}

The result of this study showed that frequency of the GG genotype was higher than GA genotype. However, AA genotype was not found in this study. Table 3 show the IL-6 levels according to distriution of II-6-597 $\mathrm{G} / \mathrm{A}$ genotypes. The association between genotypes of IL-6-597 G/A gene polymorphism and IL-6 levels was significant $(p<0.05)$.

\section{Discussion}

IL-6 is a pleiotropic cytokine that is involved in the pathophysiology of various human diseases. Human IL-6 protein consists of 212 amino acids with molecular weights ranging from 21 to $28 \mathrm{kDa}$. The signal peptide structure is composed of 27 amino acids with two potential NH2-related glycosylation sites. IL-6 is produced by various cells including monocytes, macrophages, fibroblasts, T-helper 2 cells, and endothelial cells [15], [16]. Polymorphism of IL-6-597 $\mathrm{G} / \mathrm{A}$ is associated with the risk of T2DM [11], [12].

The present study that analyzes IL-6-597 G/A gene polymorphisms has been carried out on 80 patients of type 2 diabetic at USU Hospital, Medan, Indonesia. In this study, GG genotype and $G$ allele showed the highest frequency compared to GA genotype and A allele (97.5\% vs. $2.5 \%$ and $98.75 \%$ vs. $1.25 \%)$. However, AA genotype was not found in this population.

The previous study on T2DM patients in Munich, Germany, showed different results, that is, the frequency of GA genotypes was higher than $G G$ and AA genotypes, but the GG genotype was found to be associated with the incidence of T2DM [11].

Polymorphism IL-6-597 G/A in T2DM populations has not been much studied because the SNPs are rarely found in populations over the world. According to the data of several previous studies, the populations suffering the other diseases (not T2DM) have shown that the distribution of GG genotype of IL-6-597 G/A had the highest frequency in several Asian countries such as China, Korea, and Japan [17], [18]. Same results with the current study, in those Asian countries, AA variants were also not found. In contrary, different results were found that the frequency of GA variants was higher than $G G$ and $A A$ in European countries populations, such as Finlandia, Czech, England, and Germany [19]

The possibility of ethnic differences impacted the occurrence of IL-6-597 G/A gene polymorphisms in populations in Europe and Asia. Genetic polymorphism is the difference in DNA sequence between individuals, groups, or populations. Genetic polymorphisms may be the result of accidental processes, or they may have been induced by external agents influenced by the environment. One type of polymorphism is SNPs, which is the substitution of one nucleotide in a particular sequence in the human genome [9], [19].

Around 3 million common SNPs in the human populations have been identified, of which around 1 million is used to find whether there is an association of SNPs with the susceptibility of diseases such as diabetes and cancer. In some cases, the gene variants can provide evolutionary benefits for species. Variant shape effects can be beneficial and detrimental, depending on the circumstances [20].

The current study only showed the distribution of genotypes and alleles in patients with T2DM, but did not show the role of IL-6-597G/A polymorphism as risk factor for T2DM. Previous studies have shown that polymorphisms IL-6-597 G/A play a role in defense against T2DM. In the previous study, it was found that $A$ allele was associated with a decrease in IL-6 levels [21]. The study of type 2 diabetic at USU Hospital found that IL-6 levels in the GG genotype group were higher than the GA+AA group and a significant association was found between the IL-6-597 G/A polymorphism and IL-6 levels.

Further, the study needs to be conducted to see whether the polymorphism of IL-6-597 G/A and IL-6 levels are associated with the occurrence of T2DM with the study design including a healthy control group.

\section{Conclusion}

In this study, it was indicated that the frequency distribution of the IL-6 GG genotype (-597 G/A gene 
polymorphism) was higher than the GA variant, and no AA variant was found in this population. These results showed a similarity with several countries populations in Asia that may be due to ethnic similarity. This study also showed that IL-6 levels in the GG genotype group were higher than the GA+AA group and showed a significant association ( $p<0.05$ ). The IL-6-597 G/A gene polymorphism may be influence the II- 6 levels.

\section{Acknowledgments}

The work is supported by research grant from Penelitian Dasar Unggulan Perguruan Tinggi of the year 2019 (Grant No. 21/2019). The authors are thankful to Ministry of Research and Technology and the Higher Education Republic of Indonesia, and also all the subjects who participated in this study.

\section{References}

1. Cho N, Shaw JE, Karuranga S, Huang $Y$, da Rocha Fernandes JD, Ohlrogge AW, et al. IDF Diabetes Atlas: Global estimates of diabetes prevalence for 2017 and projections for 2045. Diabetes Res Clin Pract. 2017;19:43-6. https://doi. org/10.1016/j.diabres.2018.02.023

2. Riset Kesehatan Dasar. 2018. Hasil Utama Riskesdas Balitbangkes Kementerian Kesehatan. Available online from: https://www.litbang.kemkes.go.id/laporan-riset-kesehatandasarriskesdas/ [Last accessed: 20 Sep 2020].

3. Chan M. Global Report on Diabetes. Vol. 58. Geneva: World Health Organization; 2014. p. 1-88.

4. American Diabetic Association. 2 Classification and diagnosis of diabetes: Standards of medical care in diabetes. Diabetes Care. 2018;41(1):S137-43. https://doi.org/10.2337/dc19-s002

5. Fauci AS, Kasper DL, Longo DL, Braunwald E, Hauser SL, Jameson JL, et al. Harrison's Principles of Internal Medicine. $17^{\text {th }}$ ed., Vol. 38. New York: McGraw-Hill Education; 2008. p. 932-33. https://doi.org/10.1111/j.1445-5994.2008.01837.x

6. Rodwell VW, Bender DA, Botham KM, Kennelly PJ, Weil PA Harper's Illustrated Biochemistry. New York: McGraw-Hill Education; 2015. p. 693.

7. Fernández-Real JM, Broch $\mathrm{M}$, Vendrell $\mathrm{J}$, Gutiérrez $\mathrm{C}$, Casamitjana R, Pugeat M, et al. Interleukin-6 gene polymorphism and insulin sensitivity. Diabetes. 2000;49(3):517-20. https://doi. org/10.2337/diabetes.49.3.517 PMid:10868978

8. Banerjee M, Saxena M. Genetic polymorphisms of cytokine genes in type 2 diabetes mellitus. World $\mathrm{J}$ Diabetes. 2014;5(4):493. https://doi.org/10.4239/wjd.v5.i4.493

\section{PMid:25126395}

9. Ismail S, Essawi M. Genetic polymorphism studies in humans. Middle East J Med Genet. 2012;1(2):57-63. https://doi. org/10.1097/01.mxe.0000415225.85003.47

10. Kristiansen OP, Mandrup-Poulsen T. Interleukin- 6 and diabetes: The good, the bad, or the indifferent? Diabetes. 2005;54(2):S114 24. https://doi.org/10.2337/diabetes.54.suppl_2.s114 PMid:16306329

11. Illig T, Bongardt F, Schopfer A, Muller-Scholze S, Rathmann W, Koenig W, et al. Significant association of the interleukin-6 gene polymorphisms C-174G and A-598G with Type 2 diabetes. J Clin Endocrinol Metab. 2004;89(10):5053-8. https://doi.org/10.1210/ jc.2004-0355 PMid:15472205

12. Boeta-Lopez K, Duran J, Elizondo D, Gonzales E, Rentfro A Schwarzbach AE, et al. Association of interleukin-6 polymorphisms with obesity or metabolic traits in young Mexican-Americans. Obes Sci Pract. 2018;4(1):85-96. https:// doi.org/10.1002/osp4.138 PMid:29479468

13. Scheller J, Chalaris A, Schmidt-Arras D, Rose-John S. The proand anti-inflammatory properties of the cytokine interleukin-6. Biophys Acta Mol Cell Res. 2011;1813(5):878-88. https://doi. org/10.1016/j.bbamcr.2011.01.034

PMid:21296109

14. Dosseva-Panova V, Mlachkova A, Popova C, Kicheva M. Evaluation of interleukin-6, lymphotoxin- $\alpha$ and TNF- $\alpha$ gene polymorphisms in chronic periodontitis. J IMAB Ann Proc Sci Papers. 2015;21(3):868-75. https://doi.org/10.5272/ jimab.2015213.868

15. Tanaka T, Narazaki M, Kishimoto T. IL-6 in inflammation immunity, and disease. Cold Spring Harb Perspect Biol. 2014;6(10):16295-6. https://doi.org/10.1101/cshperspect. a028456

PMid:25190079

16. Naseem $S$, lqbal $R$, Munir T. Role of interleukin- 6 in immunity : A review. Int J Life Sci Res. 2016;4(2):268-74.

17. Pan M, Gao SP, Jiang MH, Guo J, Zheng JG, Zhu JH. Interleukin 6 promoter polymorphisms in normal Han Chinese population: Frequencies and effects on inflammatory markers. J Investig Med. 2011;59(2):272-6. https://doi.org/10.2310/ jim.0b013e318206ffad

PMid:21157373

18. Gao SP, Liang S, Pan M, Sun RL, Chen C, Luan H, et al Interleukin-6 genotypes and serum levels in Chinese Hui population. Int J Clin Exp Med. 2014;7(9):2851-7. PMid:25356148

19. Karki R, Pandya D, Elston RC, Ferlini C. Defining mutation and polymorphism in the era of personal genomics. BMC Med Genomics. 2015;8(1):1-7. https://doi.org/10.1186/ s12920-015-0115-z PMid:26173390

20. Teama S. DNA polymorphisms: DNA-based molecular markers and their application in medicine. In: Liu Y, editor. Genetic Diversity and Disease Susceptibility. London, UK: Intechopen; 2018. p. 25. https://doi.org/10.5772/intechopen.79517

21. Hildreth CJ. Inflammation and diabetes. JAMA 2008;300(21):2476. https://doi.org/10.1001/jama.2008.737 